Visoka škola strukovih studija za obrazovanje vaspitača

\title{
AKTUELNI KONCEPT RANE INTERVENCIJE U IDEJAMA KOMENSKOG
}

\begin{abstract}
Apstrakt
Porodice dece koja su drugačija, imaju svoje specifičnosti, izazove i teškoće u ostvarivanju porodičnih funkcija, kao i u pružanju adekvatne podrške svom detetu u učenju i razvoju. Programi rane intervencije podstiču detetov razvoj u ranom detinjstvu i pružaju podršku porodici, jer daju najbolje rezultate vezano za napredovanje dece. Svakom detetu, posebno u ranom uzrastu je porodica $i$ dom prirodno, poznato $i$ realno okruženje, o čemu je već i Komenski pisao u Materinskoj školi, gde je isticao da su uz uputstva i informisanje, roditelji spremni sa decom da vežbaju potrebne sposobnosti $i$ veštine do polaska u školu. Nova koncepcija rane intervencije takođe prepoznaje roditeljske kompetencije uz podršku transdisciplinarnog tima i partnerstvo, da se u porodičnom okruženju realizuje podsticaj deteta u ranom uzrastu. U ranom detinjstvu važnost igre, delanja i vršnjačke interakcije odnosno razvijanja odnosa su prepoznata u idejama Komenskog, a i polazišta su nove koncepcije reformisanog predškolskog programa Godine uzleta, što je u skladu sa ranom inkluzijom u okviru rane intervencije. U radu je predstavljen aktuelni koncept rane intervencije sa utemeljenjem u idejama Komenskog vezano za porodične snage i pružanje podrške porodici.
\end{abstract}

Ključne reči: rana intervencija, materinska škola, porodično okruženje, podrška porodici

\section{Značaj rane intervencije}

Porodice dece sa poteškoćama u učenju, smetnjama u razvoju ili invaliditetom su drugačije od porodica dece tipičnog razvoja. Za svaku porodicu najbitnija je njena funkcionalnost, a to je dodatno značajno u porodicama koja su na ovaj način drugačije. Različitost ovih porodica se ogleda u specifičnostima po strukturi, dinamici i ulogama, jer ono što utiče na jednog člana utiče i na sve ostale članove porodice. Odnosi između

\footnotetext{
${ }^{1}$ otilia.velisek@gmail.com

${ }^{2}$ svilar.marija@gmail.com
} 
članova, njihovo građenje i kvalitet od ključne su važnosti za funkcionalnost porodice, kao i koliko porodica izlazi u susret potrebama i interesovanjima svakom pojedinom članu i na koji način pruža podršku. Ove porodice imaju velike izazove i teškoće u ostvarivanju funkcija savremenih porodica što obuhvata uloge: reprodukciju, emocionalnu, zaštitnu, ekonomsku, vaspitno-obrazovnu i ulogu zabave i razonode. Ova specifična porodična situacija može i ojačati i ugroziti porodične odnose i dinamiku, jer roditelji, a i drugi članovi porodice prilikom spoznaje da dete ima smetnje u razvoju ili invaliditet često iskuse čitav spektar intenzivnih i uznemirujućih osećanja. Emocionalne reakcije koje prolaze roditelji prilikom suočavanja sa činjenicom (najčešće dijagnozom) i koje preživljavaju su faze šoka, tuge, besa, poricanja, usamljenosti i poslednja faza prihvatanja (Velišek-Braško i Svilar, 2017). Na osnovu ovog prikazanog se mogu zaključiti specifičnosti i poteškoće porodica koje su drugačije i prepoznati velika potreba za podrškom porodica u ovakvim situacijama kao i njihovo osnaživanje za što bolje funkcionisanje.

Porodično okruženje, na prvom mestu roditelji (ili staratelji), a i ostali članovi porodice deteta, u periodu odrastanja su od najveće važnosti za podsticaj razvoja deteta, pružanje podrške u procesu vaspitanja i obrazovanja, podupiranja i ostvarivanja svih mogućih potencijala deteta. Opisana porodična delovanja i zaduženja su od još većeg značaja u porodicama u kojima postoji dete sa potrebom za dodatnom podrškom u razvoju i učenju. Podsticaj razvoja deteta sa potrebom za dodatnom podrškom u ranom uzrastu se naziva ranom intervencijom i o njenom značaju su i pisali i govorili brojni relevantni autori u inostranstvu (Czeizle \& Kemény, 2015) i kod nas u Srbiji (Glumbić i Jačevski, 2018; Golubović, 2018; Rudić, 2018). Pod ranom intervencijom se ranije podrazumevao period ranog razvoja deteta $i$ to od 0 do 3 godine, ali danas se rano detinjstvo shvata šire i odnosi se na period od 0 do 5 , čak i 6 godina. Te se rana intervencija odnosi na decu uzrasta $0-6$ godina, kod koje postoji odstupanje u razvoju i podrazumeva sistematičan plan razvojnog programa deteta, koji obuhvata i pomoć i podršku porodici. Programi rane intervencije veliki akcenat stavljaju na „borbu“ protiv predrasuda i upozoravaju da rana intervencija može da postane kasna intervencija ako se kasno obrate stručnjacima za pomoć i podršku i kasno krenu sa dodatnim podsticajem razvoja deteta i u pružanju dodatne podrške u učenju.

Činjenica je da rani razvoj dece, koji obuhvata period od rođenja do 5-6 godine života (Czeizel \& Kemény, 2015), ima najveći uticaj na kasniji razvoj dece, posebno kada govorimo o ranoj intervenciji kod dece sa smetnjama u razvoju i invaliditetom. Programi rane intervencije obuhvataju ranu dijagnostiku, ranu intervenciju u radu sa detetom, osnaživanje porodice u vidu savetovanja, informisanja i obrazovanja za podsticaj razvoja deteta i ranu inkluziju, odnosno uključivanje deteta u redovan vaspitno-obrazovni sistem. Time rana intervencija ima veći uticaj na podsticaj razvoja deteta u različitim oblastima, kao i na prevenciju mogućih poteškoća u razvoju i funkcionisanju. Osnovna karakteristika ranog uzrasta jeste sposobnost brzog učenja, jer se ve- 
ćina neuronskih veza gradi u mozgu u periodu ranog detinjstva što čini temelje daljeg razvoja deteta (UNICEF, 2018).

U svetu i u Evropi se u poslednjih šezdeset godina rana intervencija kod dece kojoj je potrebna dodatna podrška u razvoju i učenju smatra ključnom u procesu podsticaja razvoja i napredovanja dece i osnaživanja porodice (Velišek-Braško i Beljanski, 2014). Tokom ovog kratkog istorijskog osvrta na ranu intervenciju dece kojoj je potrebna dodatna podrška i podsticanje razvoja, menjao se odnos stručnog kadra (terapeut, stručni saradnik, logoped i defektolog...), kao i sama uloga roditelja u vaspitanju i obrazovanju i u ranoj intervenciji (Czeizel \& Kemény, 2015):

- Oko 1960-ih godina - roditelj je „laik“ (a stručni kadar „svemoćan“), na roditelje se gledalo kao na neznalice, a podsticaj razvoja deteta je zavisio isključivo od posebnog stručnog kadra, koji radi tretmane sa detetom.

- Oko 1970-ih godina - roditelj postaje „,trener“, to je period kada su stručnjaci obučavali roditelje da uvežbavaju određene aktivnosti, sposobnosti i veštine kod deteta uz njihovu superviziju. Roditelji su bili uključeni u podsticaj razvoja deteta, ali u inferiornom položaju, dominantnu ulogu u programu rane intervencije imao je stručan kadar.

- Oko 1980-ih godina - moto postaje „snažne majke“, tada su fokus u ranoj intervenciji stavili i na osnaživanje roditelja, a posebno majki koje su prepoznate kao ključne osobe u procesu učenja dece, te je njihovo osnaživanje pored stručnih sadržaja za pružanje podrške svom detetu bilo usmereno i na njihovo psihičko osnaživanje.

- Oko 1990-ih godina - roditelj je ,ppartner“, tj. roditelji su dobili ravnopravan položaj u procesu vaspitanja i obrazovanja dece, odnosno pravo da ravnopravno odlučuju, planiraju i realizuju podsticaj razvoja i učenje deteta.

- Od 2010. godine - roditelji su postali „lovci na talente“ u traganju za jakim stranama deteta, isticanju posebnih sposobnosti i posebnih veština deteta kao izuzetnosti, fokus su stavili na podsticanje i razvoj samo prepoznatih jakih strana deteta (nekad i talenta), ponekad čak i zanemarujući druge oblasti razvoja.

Kod dece kojoj je potrebna dodatna podrška u podsticanju razvoja, rano uočavanje teškoća i primena intervencija vode značajno boljim ishodima u razvoju dece, njihovom funkcionisanju i prevazilaženju prepreka i poteškoća u svakodnevnom životu. Brojne studije i istraživanja potvrđuju značaj ranog otkrivanja poteškoća i započinjanje tretmana u ranom detinjstvu, odnosno od rođenja do šeste godine (Rudić, 2018), tj. do polaska deteta u školu. Rana dijagnoza je preduslov za ranu intervenciju kod dece kojoj je potrebna dodatna podrška u podsticanju razvoja u ranom uzrastu. Neophodan je timski pristup tokom procene prirode poteškoća, donošenja zaključaka, kreiranja plana podsticanja razvoja i realizacije personalizovanog plana učenja deteta, odnosno plana rane intervencije. Plan u okviru rane intervencije obuhvata mere podrške detetu i porodici. Interdisciplinarnost je osnovni princip rane intervencije, s obzirom da obuhvata različite službe iz različitih sektora (zdravstvo/pedijatrija i ra- 
zvojno savetovalište, obrazovanje/predškolska ustanova tj. vrtić i socijalna zaštita/centar za socijalni rad) i različite profesije (lekare, medicinske sestre, medicinske sestre vaspitače, vaspitače, pedagoge, psihologe, terapeute, defektologe, logopede, socijalne radnice...). Guralnik ranu intervenciju definiše kao sistem koji je osmišljen da razvija i podržava one porodične interakcije koje potpomažu dečiji razvoj. On stavlja u fokus odnos i interakciju roditelj-dete, porodično usmerena iskustva deteta i pružanje pomoći roditeljima da bi obezbedili maksimalno detetovo zdravlje i sigurnost (Guralnick, 2011). Rana intervencija predstavlja podršku sistema u prvim godinama života deteta sa smetnjama u razvoju ili invaliditetom, kojem je potrebna dodatna podrška u podsticanju razvoja, sa ciljem da unapredi razvoj deteta i pruži podršku porodici, odnosno njenim članovima (Svilar, 2018). Svrha rane intervencije je maksimalno iskorišćavanje svih kapaciteta deteta, prevencija ili barem ublažavanje razvojnih problema, kao i angažovanje i uključivanje svih dostupnih sistema podrške (Soriano, 2015, prema: Svilar, 2018), što obuhvata zdravstvenu zaštitu i tretmane, ranu inkluziju, odnosno institucionalizovano vaspitanje i obrazovanje u ranom uzrastu, kao i socijalnu zaštitu.

Ranije je medicinski model rane intervencije bio primenjivan sa tendencijom da se otklanjaju loši činioci koji negativno utiču na razvoj deteta, nasuprot tome postoji socijalni model rane intervencije sa pristupom da se unapredi i osnaži porodica i spoljašnji društveni faktori koji utiču na razvoj deteta (Glumbić i sar., 2013, prema: Svilar, 2018). Radi funkcionalnije povezanosti neophodnih disciplina, odnosno sektora koja imaju svoje dragocene (specifične) resurse, danas se već govori o transdisciplinarnom (trans-resorskom i trans-sektorskom) pristupu rane intervencije, što se i pilotira kao model u Srbiji od 2017/2018 godine. Transdisciplinarni pristup podrazumeva holističko shvatanje deteta (i porodice) i integrisani način razvoja i učenja, te u skladu sa tim se pruža podrška i pomoć detetu i porodici kroz individualizovane usluge. Model intervencije je zasnovan na dnevnim rutinama i drugim aktivnostima deteta i porodice (UNICEF, 2018), a usluga se kreira u skladu sa potrebama i prioritetnim oblastima i porodice i deteta. Podrška za podsticanje razvoja se pruža u detetovom prirodnom okruženju, zajednički, sa transdiciplinarnim timom stručnjaka koji izlazi u susret potrebama deteta i porodice. Ono što je posebno istaknuto i što je drugačije u novom modelu rane intervencije, jeste usmerenost na porodicu. Potrebne su službe i stručnjaci koji su senzibilisani za brige porodica, koji su kompetentni da razvijaju i grade porodične snage, pronalaze porodične kapacitete, osnažuju porodične veštine u pružanju podrške detetu i podsticanju detetovog razvoja u porodičnom okruženju.

Osnaživanje porodica za primenu modela intervencija zasnovanih na rutinama je i u skladu sa opštim principom rane intervencije Američke akademije pedijatara (American Academy of Pediatrics, prema: Rudić, 2018) da pružanje usluga započinje što pre, nakon postavljanja dijagnoze i da je potrebno obezbediti podsticajne aktivnosti za učenje minimum 15-25 sati nedeljno, 12 meseci godišnje, odnosno od 3 do 5 sati dnevno, svaki radni dan, tokom cele godine. Tako intenzivan rad samo na individualnim tretmanima kod terapeuta je vrlo teško izvodljiv, bez aktivnog učešća porodi- 
ce, odnosno roditelja. Zbog datih preporuka vezanih za intenzitet podsticaja razvoja i učenja deteta na ranom uzrastu potpuno je opravdan pristup prema novom modelu $\mathrm{cu}$ Srbiji) da se intervencije rade u detetovom prirodnom okruženju, a to jeste u porodici i vrtiću koje dete pohađa. Dete je učesnik odnosno subjekat, a ne objekat tretmana, i to aktivan učesnik sopstvenog razvoja i učenja u intervencijama koje obuhvataju dodatni podsticaj razvoja i učenja i podršku, odnosno čitav niz strategija za izlaženje u susret potrebama deteta i porodice.

U okviru rane intervencije uvažavajući jedinstvenost svakog deteta i porodice će se planirati i razvijati strategija podsticanja razvoja deteta, odnosno vrsta intervencija, njihovo trajanje i učestalost, kao i mesto izvođenja i to će biti deo individualnog plana podrške porodici. Plan će se prilagoditi detetu i porodici prema profilu deteta (pedagoški profil sa identifikovanim jakim stranama i potrebama za dodatnom podrškom, dijagnozom, prepoznatim simptomima i razvojnim mogućnostima) osobenostima i karakteristikama, interesovanjima, kao i realnim porodičnim mogućnostima.

U okviru ranih intervencija, inkluzija odnosno rana inkluzija se takođe ističe kao značajan faktor podsticanja razvoja deteta. Značaj rane inkluzije, odnosno institucionalnog vaspitanja i obrazovanja dece ranog uzrasta, podrazumeva pohađanje vrtića u ranom detinjstvu, jer pruža adekvatnu strukturu i organizaciju vremena, prostora, kao i socijalnu i fizičku sredinu. U vrtiću su deca izložena profesionalnom i stručnom pristupu odraslih, na prvom mestu vaspitača i ostalih aktera, interakcijama i komunikacijom sa drugom decom, što omogućava participaciju dece u različitim socijalnim iskustvima, aktivnostima i igrama koje maksimalno podstiču razvoj svakog deteta (Velišek-Braško i Beljanski, 2017). Socijalni odnosi u predškolskom periodu (što se u najvećoj meri omogućava ranom inkluzijom) povezani su sa socijalnim kompetencijama. Pokazalo se da su socijalni odnosi u ranom detinjstvu sa vršnjacima visoko povezani sa prilagođavanjem dece školskom okruženju i sa uspehom u školi (Blatni i sar., 2012).

Za dete sa poteškoćama u učenju, smetnjama u razvoju i/ili invaliditetom podrška koja mu je potrebna u ranom detinjstvu, a i kasnije, na prvom mestu je podrška roditelja i porodice. Ali podrška treba i roditeljima, odnosno porodici deteta u građenju partnerstva sa stručnjacima i relevantnim ustanovama, kao i edukacija i osnaživanje roditelja o specifičnostima stanja deteta i o načinima podsticaja razvoja, vaspitanja i obrazovanja. Takođe je važna podrška roditeljima u negovanju dobrih odnosa unutar porodice, kao i osnaživanje roditelja da brinu i o sebi. U periodu detinjstva važan segment je i uspostavljanje načina funkcionisanja u svakodnevnom životu, životu u kući i u zajednici (Glumbić i Jačevski, 2018). Prilikom pružanja podrške u ranom detinjstvu koraci koje treba preduzeti su: uspostaviti formalnu i neformalnu mrežu pružanja podrške porodici i detetu i to u skladu sa mogućnostima lokalne zajednice, odnosno u realnom kontekstu; realizovati program rane intervencije koji je namenjen specifičnim stanjima deteta i u skladu sa potrebama za podrškom i podsticanju razvoja, omogućiti detetu pristup i učešće u podsticajnom fizičkom i socijalnom okruženju, a za to je najpogodnija rana inkluzija, u vrtićima, gde ima mogućnost uspostavljanja interakcije i sa 
fizičkim i sa socijalnim okruženjem, građenje i razvijanje odnosa kroz igru, druženje, rutinske aktivnosti, u planiranim situacijama za učenje u autentičnim situacijama ...

\section{Model rane intervencije u prirodnom i realnom okruženju deteta}

U razvijenim zemljama insistira se na decentralizaciji službi i samo usko specijalizovane službe su centralizovane. U skladu sa tim, u skandinavskim zemljama lokalne vlasti su odgovorne za koordinaciju, stručnu i ekonomsku pomoć deci kojoj su potrebne usluge rane intervencije i njihovim porodicama. U Nemačkoj sve pokrajine pružaju uobičajenu ranu intervenciju u trajanju od prve do treće godine ili predškolsku intervenciju. U Portugalu se uz saglasnost Ministarstva za obrazovanje osoblje iz specijalnih škola uključuje u multidisciplinarne timove za ranu intervenciju. Postoje razlike u strukturi ovih službi i uglavnom su to državne službe na lokalnom ili regionalnom nivou, ali postoje i privatne službe kojima upravljaju razna udruženja, one postoje i rade uporedo. U Austriji se medicinske intervencije i tretmani ostvaruju u bolnicama i oni se finansiraju iz državnog budžeta, međutim postoje i državni i privatni centri koji su uže specijalizovani i pružaju negu i tretman. Za malu decu, do godinu dana starosti, pomoć kod kuće je uobičajena i ona se sprovodi u Danskoj, Islandu, Luksembergu, Norveškoj i Švedskoj. Cilj je da i druge zemlje uvedu ovu praksu i da kućna nega kao oblik rane intervencije bude na prvom mestu (Marković i Arsić, 2011).

Aktuelni „novi“ model rane intervencije, koji je prilagođen za Srbiju i u fazi je implementacije nakon pilotiranja uz podršku UNICEF-a i Fonda za otvoreno društvo, polazi od holističkog shvatanja deteta i porodice u njegovom autentičnom i realnom kontekstu. Kada se prepoznaju i identifikuju pokazatelji da dete kasni u razvoju, ima invaliditet, atipično se ponaša, da je sa emocionalnim ili društvenim teškoćama (UNICEF, 2018), porodica se uključuje u program podrške i usluge rane intervencije. Promena paradigme rane intervencije u najvećoj meri se odgleda $u$ orijentisanosti na porodicu, osnova je da se upozna i razume njihov svakodnevni život, svakodnevne aktivnosti, rutine, njihova autentičnost, interesovanja, potrebe za podrškom, kao i njihove snage i resursi čime raspolažu. U tu svrhu formira se tim stručnjaka iz različitih sektora (transdisiplinarni tim) za ranu intervenciju i određuje se koordinator. Sa porodicom se obavlja temeljan polustruktuiran intervju radi upoznavanja i prikupljanja što više informacija o porodici i detetu i o njihovom svakodnevnom životu. Na osnovu dobijenih informacija kroz razgovor izrađuje se tzv. eko-mapa porodice, odnosno slikovit, shematski prikaz porodice, njihovih kontakata, formalne i neformalne mreže podrške oko porodice. Sve ovo pomenuto ide $u$ funkciju boljeg razumevanja porodice i njihove ekologije što obuhvata njihov realni kontekst, porodičnu dinamiku, njihove snage i resurse, kao i interakciju sa okruženjem. Na osnovu sticanja celokupne slike o detetu i porodici, kreira se Individualizovan plan podrške porodici, u okviru koga se definišu funkcionalni ciljevi koji su zasnovani na potrebama porodice i deteta u skladu sa njihovim prioritetima i planiraju se intervencije. Transdisciplinarni tim pruža integrisane usluge porodici i detetu i daje podršku i pomoć 
u prirodnom okruženju deteta, odnosno u porodici i u vrtiću. Kućne posete u okviru rane intervencije su takođe novi pristup u ovom konceptu rane intervencije, umesto da dete ide na tretmane kod terapeuta, defektologa, logopeda, psihologa... Profesionalac ispred tima obavlja posete i pruža pomoć i podršku sa postojećim resursima, uslugama, savetuje, podučava porodicu kako i šta da rade sa detetom. Specifičnost transdisciplinarnog pristupa u je kolaborativno-konsultativnoj brizi o detetu, kada se prilikom poseta porodici i vrtiću, pruža podrška, savetuju i podučavaju roditelji i vaspitači u primeni strategija u podsticanju razvoja deteta u realnom okruženju i u sklopu detetovih rutina. Ova saradnja i konsultacija između roditelja, predstavnika tima rane intervencije, vaspitača i drugih relevantnih stručnjaka, radi na određivanju detetovih snaga, prepoznavanju potreba za podršku i dodatni podsticaj, kao i na određivanje strategije za unapređivanje razvoja deteta.

Novi model rane intervencije koncipiran je na shvatanju i razumevanju da deca, posebno u ranom detinjstvu ,najbolje uče kroz svakodnevne aktivnosti i interakcije sa ljudima koji ih okružuju“ u poznatom okruženju (Đorđević i Koruga, 2018: 5). Svakodnevne aktivnosti i interakcije obuhvataju delanje deteta u rutinskim praktično-životnim aktivnostima, igri, planiranim situacijama za učenje, ritualima ili autentičnim događajima, to sve kroz odnose i građenje odnosa sa drugima, odraslim ljudima (roditelji, vaspitači i drugi poznati i relevantni ljudi) i vršnjacima (Godine uzleta, 2018). Na ovaj način se obezbeđuje dobrobit deteta kome je potrebna dodatna podrška i podsticaj razvoja, jer se omogućava da se dete oseća dobro i funkcioniše uspešno, da jeste u svom prirodnom okruženju, da hoće da radi (dela), da radi ono što može i ume sa poznatim ljudima i to kroz odnose i u raznim situacijama, jer tu pripada, tu je prihvaćen i participira svakodnevno.

\section{Ideje Komenskog u Materinskoj školi i rana intervencija}

Komenski, među najznačajnijim ličnostima u istoriji pedagogije, još je u periodu 1630-1632 napisao Informatorijum materinske škole, odnosno Uputstvo za materinsku školu (Zaninović, 1985) prvu knjigu o predškolskoj pedagogiji. U okviru koje je napisao pedagošku koncepciju za predškolski uzrast, obuhvatajući period ranog detinjstva od rođenja do šeste godine. Kasnije 1653. izdata je proširena verzija Materinske škole, pod nazivom Škola detinjstva (Komenski, 2000).

Prema Komenskom, predškolsko vaspitanje i obrazovanje predstavlja osnov za dalje učenje i razvoj, odnosno građenje. U delu Velika didaktika govorio je o veštini podučavanja i isticao je njihove principe, među njima su princip prirode (Ne preduzima se ništa u nevreme), građa pre oblika (Priroda priprema građu pre nego što joj počne davati oblik) i još drugih, koji su povezani sa prirodom, prirodnim zakonitostima i ustrojstvom (Zaninović, 1985: 91).

$\mathrm{Na}$ decu je gledao kao najveći božji dar, da su deca veliko i dragoceno blago. U tim njegovim idejama se ogleda verovanje da su deca puna potencijala, koje treba razvijati i vežbati. O tome je pisao u prvom poglavlju Materinske škole (Komenski, 
2000), dok se u drugom poglavlju bavio verovanjem da je Bog ukazao poverenje roditeljima, da umeju, mogu i znaju čemu treba decu da uče, odnosno da imaju veštine kao roditelji za vaspitanje i obrazovanje dece u predškolskom periodu. On je naveo da je Bog darovao roditeljima umeća i pruža im priliku da razumno delaju i da se brinu o deci. Ukazao je da roditelji mogu više da pruže deci osim da ih nahrane i obuku. Oni umeju da vežbaju, odnosno uče decu da neguju plemenitost, raznim veštinama i potrebnim stvarnim koje će im biti potrebne u odraslom dobu, što se može u savremenim shvatanjima povezati sa funkcionalnim znanjima i o razvoju životnih kompetencija.

U četvrtom poglavlju Komenski je u trinaest tačaka definisao šta sve treba vežbati sa decom u ranom detinjstvu do šeste godine, u njima je detaljno predstavio svoje ideje za oblast pobožnosti, ali pored toga je istakao da deca u porodičnom, kućnom vaspitanju i obrazovanju mogu učiti i vežbati oblasti iz nauke i da razvijaju jezik. On je prepoznao i jačanje zdravlja i snage kod dece u ovom periodu, zalagao se da majke doje decu svoju, a ne dojilje, jer je ukazivao i na povezanost majke i deteta, kao i na zdravu ishranu.

„Kada deca počnu da sede, stoje, trče, treba ih čuvati od povreda: tu će poslužiti stolice, štule... Negde postoji običaj da se deci na glavu stavlja kapa, koja će kao kobasica ispunjena vatom" štititi od udara i povreda pri padu (Komenski, 2000: 37). U ovim idejama savetuje i podučava roditelje kako da podstaknu i omoguće razvoj deteta, da se služe stvarima iz okruženja u realnom kontekstu, da po potrebi prilagode uslove, kao što je kapa sa vatom, da dete bude aktivno, ali i bezbedno, a ne da bude sputano. U ideji Komenskog se može prepoznati važnost podsticaja baš u ranom detinjstvu, kada je napisao ,dete je dragi kamen vredniji od zlata, ali krhkije nego staklo,..., nastala šteta nadoknaditi se ne može“ (Komenski, 2000: 37).

Ukazivao je kako i šta treba roditelji da omoguće i da rade sa decom: ljuljaju, miluju u naručju, pevaju, sviraju zvečkom, nose ih u dvorište i baštu, da ih ljube i grle i da se igraju sa njima. Govorio je i o dečjoj igri i uvideo značaj igre u ranom detinjstvu, kao i da se igranje dešava u interakciji između dece ili između dece i roditelja, odnosno kroz odnose. Naglasio je i sledeće aktivnosti koje osvežavaju duh i telo deteta: trčanje, skakanje, muzika, slike, pozorišne predstave i aktivnosti koje su primerene detetovom vidu, sluhu i ostalim čulima. Roditelji mogu i približiti različite sadržaje deci, čak i politiku, ali naglasio je i važnost vršnjačke interakcije i igre u poglavlju gde piše o vežbanju sposobnosti shvatanja, i to svakodnevno i na ulici „,dete detetu može bolje izoštriti duh nego bilo ko drugi“ (Komenski, 2000: 45). On je već tada ukazivao da neka dece prirodno usvajaju znanja, a dok kod nekih to treba vežbati, i isticao da sa decom treba raditi na dečji način u skladu sa detetovim karakteristikama.

Za rano detinjstvo je rekao da je to nežan uzrast koji zahteva više brige nego što to učitelj može da pruži, zato o deci treba brinuti kod kuće, ono što deca mogu sama, sopstvenom voljom, kroz igru, neprimetno u kućnom okruženju, i time mislio na porodično vaspitanje u celini. 
U idejama i savetima Komenskog se mogu prepoznati shvatanja savremenog pristupa $\mathrm{u}$ ranoj intervenciji, jer ukazuje veliko poverenje u roditeljske kapacitete $\mathrm{u}$ ranom detinjstvu, ističući poseban značaj ovog osetljivog perioda razvoja deteta, kao i da potencijale dece roditelji u porodičnom okruženju mogu vežbati. On prepoznaje snage porodice, što je u skladu sa novim modelom rane intervencije koji je baziran na prirodnom detetovom okruženju i zasnovan na porodičnim rutinama, kao i na verovanju u roditeljske kompetencije da brinu o detetu i da mu podstaknu razvoj, omoguće učenje, da vežbaju sa njima, uz savetovanje i podučavanje.

\section{Zaključak i pedagoška implikacija}

Poverenje u roditeljske kompetencije za vaspitanje i obrazovanje, podsticaj razvoja i učenja deteta predškolskog uzrasta, još je Komenski prepoznao u prvoj polovini XVII veka, kao i značaj porodičnog okruženja u ranom detinjstvu. Porodica je prirodno i realno okruženje svakog deteta, posebno deci sa poteškoćama u učenju, smetnjama u razvoju ili invaliditetom, koja su već zbog datih okolnosti ranjiva i pripadaju osetljivoj društvenoj grupi. Intervencija, odnosno podsticanje razvoja i pružanje dodatne podrške deci sa poteškoćama u učenju, smetnjama u razvoju ili invaliditetom, u ranom detinjastu je od ključnog značaja i samom detetu, kao i porodici. Kako bi se ostvario intenzivan i kontinuiran program podsticanja razvoja za dete koje se uključuje $\mathrm{u}$ ranu intervenciju, neophodno je učešće roditelja kao partnera u tom procesu $\mathrm{i}$ to $\mathrm{u}$ poznatom, prirodnom porodičnom okruženju, a ne u izmeštenoj specijalnoj ustanovi da pohađa tretmane.

Sve gore pomenuto je potrebno raditi u cilju podrške dobrobiti deteta, obuhvatajući sve dimenzije i to ličnu, društvenu i delatnu dobrobit. Iz ugla svakog deteta ostvarenje dobrobiti znači osećati se (dobro, ispunjeno, sigurno...), biti (prihvaćen, podržan, uključen...), moći (razumeti sebe i druge, istražiti svet oko sebe, spoznati svoje snage...) i umeti (uraditi, ostvariti, doneti odluku i praviti izbore, komunicirati...), što je u skladu sa koncepcijom reformisanog predškolskog programa Godinama uzleta, kao i sa novim modelom rane intervencije. Porodice je potrebno osnažiti, kako bi mogli da pruže adekvatnu podršku detetu u ranom detinjstvu i kasnije, za postizanje dobrobiti deteta, a i dobrobiti porodice da se i članovi ove drugačije porodice da osećaju ..., da budu ..., da mogu... i da umeju... 


\title{
CURRENT CONCEPT OF EARLY INTERVENTION IN THE IDEAS OF COMENIUS
}

\author{
Abstract
}

Families of children who are different, has their own uniqueness, challenges and difficulties in fulfilling family functions, as well as in giving adequate support to their child in learning and development. Programs of early intervention have a positive impact on child's development in early childhood and give support to family because they are giving the best results for children's progress. For every child, especially at an early age family and home are natural, familiar and realistic environment, about what Comenius was writing in The School of Infancy where he pointed out that with instructions and information, parents are ready to practice with children the required abilities and skills until they go to school. The new concept of early intervention also recognizes parenting competencies, with the support of a trans-disciplinary team and partnership, to foster an early-stage child support in the family setting. In early childhood, the importance of play, acting, and peer interaction, that is, developing relationships, were recognized in Comenius ideas, and they are the starting points in new conceptions of the reformed pre-school program of the Years of Ascent, which is accordance with early inclusion within early intervention. The paper presents the current concept of early intervention with foundation in Comenius ideas and family strength and support for the family.

Keywords: early intervention, school of infancy, family environment, support to family

\section{Literatura}

Blatnik, S., Selimović, S. i Mujezinović, A. (2012). Značaj rane inkluzije. Tuzla: I learn.

Czeizel, B. \& Kemény, G. (2015). A koraifejlesztéstöl a családközpontú kora gyermekkori intervencióig. A törvényi szabályozástól az interdiszciplináris szemlélet és gyakorlat megvalósulásáig a Budapesti Korai Fejlesztő Központban. Gyermeknevelés, 3(2), 77-92.

Đorđević, M., Koruga, D. (2018). Rana intervencija u porodici kao prirodnom kontekstu odrastanja. Beograd: Udruženja logopeda Srbije. Dostupno i posećeno 27.01.2020. https://www.researchgate.net/publication/329337117 Rana intervencija u porodici kao prirodnom kontekstu odrastanja,

Guralnick, M. J. (2011). Why early intervention works: A system perspective. Infants \& Young Children, 24, 6-28. 
Glumbić, N. i Jačevski, M. (2018). Karakteristike i potrebe osoba sa autizmom u različitim kontekstima i životnim dobima. Autizma, trening za inkluziju. Beograd: IPA.

Godine uzleta - Osnove programa predškolskog vaspitanja i obrazovanja (2018). Beograd: MPNTR, UNICEF, IPA i ZUOV.

Marković, O. i Arsić, J. (2011). Rana intervencija i tretman dece sa smetnjama u razvoju. PONS - medicinski časopis, 8(4), 138-145.

Komenski, J.A. (2000). Materinska škola. Preveo Spevak, Z. Beograd: Zavod za udžbenike i nastavna sredstva.

Rudić, N. (2018). Rana intervencija i zašto je važna. Autizam, trening za inkluziju. Beograd: IPA.

Situaciona analiza usluga za bebe i malu decu sa smetnjama u razvoju u Republici Srbiji. Razvoj usluga vezanih intervencije u ranom detinjstvu: mogućnosti i izazovi.(2018). Beograd:UNICEF i Fond za otvoreno društvo.

Svilar, M. (2018). Uloga defektologa u timskom radu u ranoj intervenciji kod dece sa smetnjama u razvoju ili invaliditetom. Krugovi detinjstva, 6(1-2), 148-161.

Velišek-Braško, O. i Beljanski, M. (2014). Rana intervencija i rana inkluzija u regionu, U: Razvojne karakteristike deteta u predškolskom uzrastu, Zbornik sažetaka. Novi Sad: Naučni skup sa međunarodnim učešćem.

Velišek-Braško, O., Svilar, M. (2017). Biti brat ili sestra „drugačijim” osobama, Krugovi detinjstva, 5(1), 28-38.

Zaninović, M. (1985). Jan Amos Komensky. Pedagoška hrestomatija. Zagreb: Školska knjiga, (pp 79-114). 


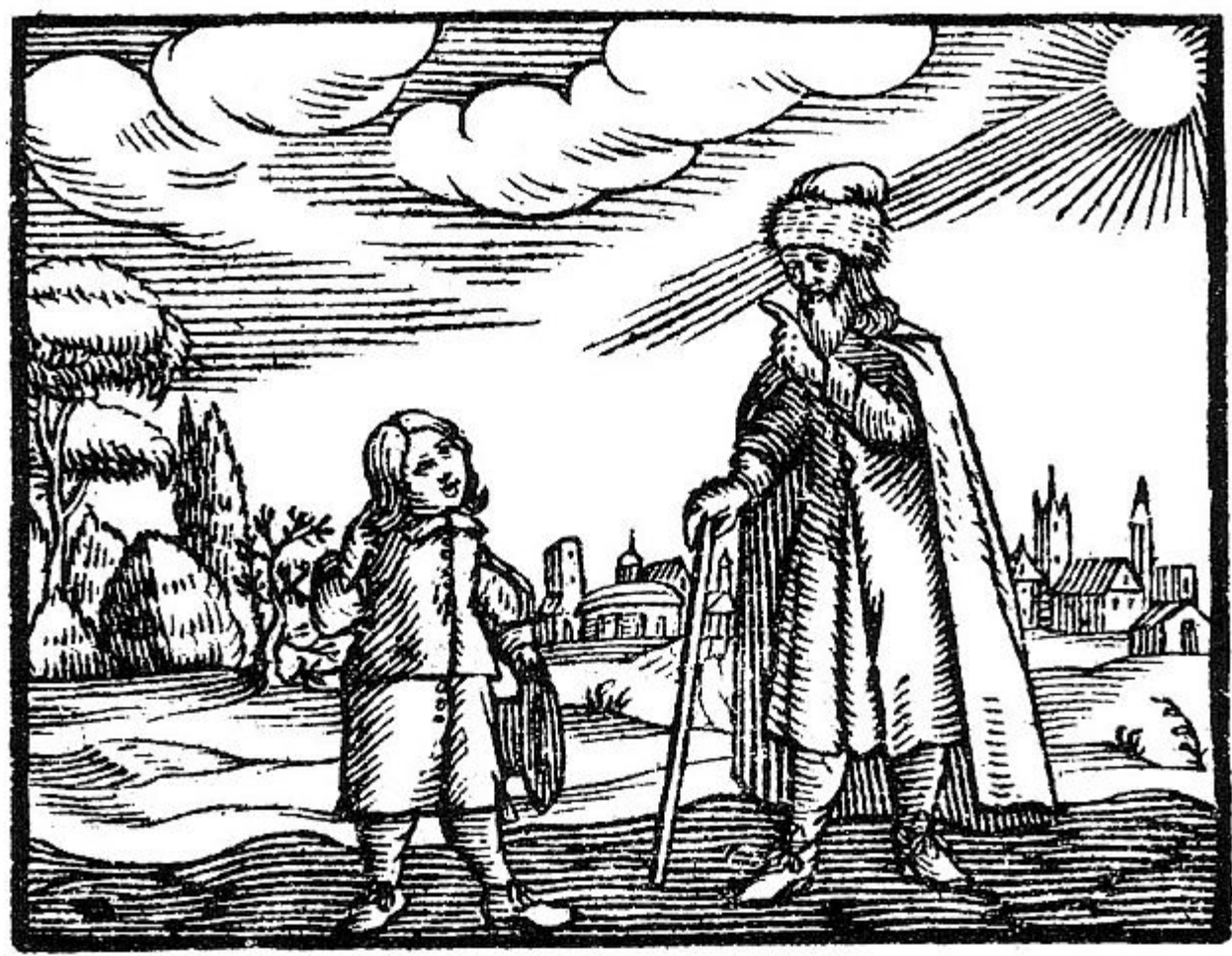

„Hajde, dečače, nauči da budeš mudar“

Naslovna slika

„Čulni svet u knjigama“ (Orbis pictus ) 1932. god. 